\title{
Corruption of Public Bureaucracy, and its Implications on the Quality of Public Services
}

\author{
${ }^{1}$ Bambang Martin Baru, ${ }^{2}$ Sripeni Rusbiyanti, ${ }^{3}$ Sumiati \\ ${ }^{1.2}$ Faculty of Social and Political Sciences, Universitas Merdeka Madiun, Indonesia \\ ${ }^{3}$ Faculty of Social and Political Sciences, Universitas Suryo Ngawi, Indonesia
}

\begin{abstract}
Public service is one of the main functions in government, so it is the government's obligation to provide good service to the public. But in reality, there are still many complaints from the public regarding procedures that are complicated, slow in their resolution. This condition provides space and opportunity for the practice of bribery in the process of managing public services. The community will look for shortcuts so that they can be given convenience in public services, although they have to add extra costs to the service personnel. Deep bribery practices because they are considered to be lacking in accordance with applicable regulations. As a result, the villagers handed over to the officers how best to facilitate the management of public services. For this reason, it is necessary to carry out comprehensive bureaucratic reforms to minimize the occurrence of community service deviations that have touched the level of village governance, the community often has to recomplete the various requirements suggested by officers in public services.
\end{abstract}

Keywords: Public services, corruption, village government

DOI: $10.7176 / \mathrm{DCS} / 9-6-08$

Publication date:June $30^{\text {th }} 2019$

\section{INTRUDUCTION.}

Public service is one of the important elements of the realization of good governance, because the main vision of the administration of government is to provide good service to the public, for which the government is very interested in making improvements to public services so far. Many cases have surfaced in various regions, where public services are still felt convoluted, procedural, and slow in its completion. The regional autonomy policy that has been running so far has not been able to answer the problems related to public services. The implementation of Law Number 32 of 2004 aims to encourage government bureaucracies to operate efficiently and responsively to the aspirations and interests of the local community. But the practice of organizing public services is still far from the expectations of the community, namely the tendency of the bureaucracy to be more oriented to the service of the interests of the authorities compared to the interests of the community, consequently the bureaucracy becomes increasingly far from its mission as a public servant. The number of complaints submitted by the community when dealing with public services, this shows that the bureaucratic apparatus is less responsive to the interests of the community, and even service users often add extra costs (bribes) in order to get convenience in public services. According to Dwiyanto, et al (2002: 74), in service culture in Indonesia it has long been known the term "know the same as know", which means there is tolerance from the bureaucratic authorities and service users to use the mechanism of bribery in getting the best service. The practice of giving bribes in public services has become a common practice in the bureaucratic environment. The bureaucratic apparatus has become accustomed to the service culture that expects the provision of money from the community.

Bureaucratic pathology in the form of giving bribes has also touched the culture of community service in the village, many villagers when dealing with public services there are always shortages of requirements that must be completed, consequently the village community must return to fulfill the requirements suggested by the service officer. This condition provides space and opportunity for bribery to make it easier for people to solve service matters. Actually, the form of bribery can be categorized as corruption, and efforts to eradicate it cannot be resolved through laws and regulations that contain the threat of legal sanctions on perpetrators of corruption, because they are related to the issue of morality and integrity of the bureaucratic apparatus. According to Dwiyanto, et.al (2006: 99), which is far more important is the commitment and responsibility of all government officials or employees to avoid the tendency towards KKN (Corruption, Collusion and Nepotism). An expert described the link between the accountability of government officials and eradicating corruption, as follows: "The mechanism of interest in incentives that benefits the public." The law alone cannot build such structures; the law does not protect the employee who exposes corruption or wrongdoing, and that does not make the decision to establish atmosphere and character of the public service so much (Dwiyanto, et. al, 2006: 99). Thus, efforts to combat corruption require commitment from the government apparatus themselves. Accountability of the bureaucracy in carrying out its duties and functions is an important factor to avoid corruption. However good a system is, if individuals as government officials are not imbued with the values of integrity, honesty and human dignity, the system will undoubtedly be misused or corrupted for a narrower purpose. Morality is a 
strategic value in the future to eradicate corruption, but if corruption is systemic where almost everyone is not able to avoid corruption transactions, it takes a more effective free measure in preventing corruption.

The dominant role of bureaucracy is one of the reasons for the growth of corrupt practices because it makes the attitudes and behavior of more arrogant bureaucratic officials function as determinants in the public service process, as Surbakti in Santoso (2008: 116) argues that: bureaucrats have great authority, so almost all aspects of people's lives are handled by the bureaucracy. The authority that is too large, even ultimately highlighting the role of the bureaucracy as policy makers rather than implementing policies, is more controlling than serving the community. This condition is reasonable if the bureaucracy is considered as the culprit of corruption in public services. Bureaucracy acts more as a civil service than civil service (Rahmat Subagio, 2012). Besides that, the influence of traditional values in the concept of pangreh praja has resulted in a very influential diagnostic culture in the environment of the public bureaucracy. According to Dwiyanto, et al. (2006: 117), public bureaucracy is structured in a very strict hierarchical structure, so that the end of power lies not in service users, but in top bureaucratic officials. Thus, the public bureaucracy autonomously develops a cultural system of superiority to superiors. In practice, this tendency will lead to improper administrative mechanisms. The most obvious is the emergence of reports that are not objective, called ABS (Originally Mr. Glad), giving tribute which sometimes leads to abuse of office, and so forth.

From some aspects of the bureaucratic pathology, improvement efforts are directed at preventing corruption, according to Effendi (2007) bureaucratic reform is needed which is directed at efforts to prevent and accelerate the eradication of corruption in a sustainable manner, in creating good, clean and authoritative governance (good governance), clean government, and free of KKN. According to Dwiyanto, et.al (2006: 119), there are several strategies that can be specifically developed, including: first, eroding the patternalistic culture; The patternalistic system may be very difficult to change when it has become a core part of culture. But that does not mean that a new awareness process is impossible. Patternalistic culture can only be reduced by developing an egalitarian culture so that the position between officials, government employees, and users of public services is the same. The system of direct election of political officials is at least a very positive development so that social contracts between officials and the community can take place more equitably. Now what is needed is a pattern of egalitarian behavior that must be cultivated among managerial officials in the public service bureaucracy. Second, orientation to service user services. Unlike most private organizations, service systems developed in public organizations tend to be less service oriented. In a democratic system, the sovereignty of service users must continue to be considered, even prioritized. Public service bureaucratic reform will only succeed if it is accompanied by a comprehensive reorientation of the thinking patterns of government employees to be more responsive to the wishes of the people as service users.

Technically, in overcoming bureaucratic corruption in every rank of the bureaucracy, it is no exception in the village government that commitment from the leadership and all of its staff is needed, as well as all elements of society. The village head as leader must have a strong determination to negate corrupt practices within his government, and provide space and opportunities for community elements to play an active role in the process of administering the government. With the involvement of elements of society can be a balance of power so as to minimize the occurrence of abuse of authority.

\section{LITERATURE REVIEW}

Reforming public services is a strategic point to begin the development of good governance, because the improvement in the performance of bureaucratic services has broad implications in economic and political life. In economic life, improving the performance of public services will encourage an investment climate that is urgently needed to accelerate the economic crisis. In the political field, improving the performance of public services can have implications for the recovery of public trust in the government. The poor performance of public services has been a trigger for a crisis of public confidence, such as the widespread demonstrations carried out in various government institutions as indicators of public dissatisfaction with government performance. Therefore, improving the performance of public services is expected to improve the image of the government in the eyes of the public, because with the better quality of service can make community satisfaction and foster public trust so that it can gain legitimacy in the public eye.

The function of public services is very urgent for the life of the community in general, because people as citizens always need services from the government, from the moment of birth to death, they always need service from the government. According to Dwiyanto (2006: 136), public services are: a series of activities carried out by the public bureaucracy to meet the needs of users. Users intended here are citizens who need public services, such as the making of identity cards (KTP), birth certificates, marriage certificates, death certificates, land certificates, business permits, building permits (IMB), disturbance permits (HO), permits take ground water, subscribe to drinking water, electricity and so on. While the orientation of public services must be aimed at the public interest, as stated by Rasyid (1998), that: public services are essentially services provided to the community. Service is not held to serve itself, but to serve the community and create conditions which allows 
each member of the community to develop their abilities and creativity to achieve common goals. Alamsyah (2011), public services are: every service activity carried out by the government, individuals, organizations and others (the others) in order to respond to the demands of individuals, groups, organizations and others that intersect with the interests of the entire population. Based on the Kepmen PAN Number. 58 of 2002 classifies three types of services based on the characteristics and nature of activities and service products produced, namely: administrative services, goods services, and services (Pasolong: 2007). Furthermore Pasolong (2007), explained that the type of administrative service is the type of service provided by the service unit in the form of recording, research, decision making, documentation and other administrative activities which overall produce final products in the form of documents, such as certificates, permits, recommendations, information and others. For example the types of land certificate services, services, IMB, population administration services (KTP, NTCR, birth certificate, and death certificate). Types of goods services are services provided by service units in the form of activities to provide and or process physical tangible materials including distribution and delivery to direct consumers (as units or individuals) in a system. Overall, these activities produce final products in the form of objects (physically realized) or those that are considered objects that provide direct added value for their use. For example the type of electricity service, clean water service, telephone service. While the type of service is the type of service provided by the service unit in the form of facilities and infrastructure as well as its support. Monitoring is based on a certain and definite operating system. The final product is a service that brings benefits to the recipient directly and is used up within a certain period of time. For example, land, sea and air transportation services, health services, banking services, postal services and fire services.

But in its development, the practice of public services cannot be separated from the practice of bribery, and even tends to have been evading all government institutions. The culture of bribery can be identified as a form of corruption, or often known as KKN (Corruption, Collusion and Nepotism). Referring to the term abuse of power in international treasures is only called corruption. Corruption comes from the Latin term comrumpere which means deviation from profanity, immoral acts, depravity, decay, damage, dishonesty, or fraud. Thus corruption is an act of contempt, slander, or other bad things (Dwiyanto, et.al, 2006: 100). The term KKN in Indonesia consists of three elements of corruption which are seen as the most widely practiced abuse of power. The element of corruption here actually refers to acts of embezzlement of state resources carried out by government officials, which in general can actually be referred to as manipulation. Then the element of collusion (collusion) refers to the phenomenon of a government official or political figure and private business people doing covert cooperation by utilizing public resources for their own interests or the interests of their group. Thus, collusion is mutually beneficial cooperation for the perpetrators but it is clearly detrimental to the public because these actions are carried out by undermining state funds. Whereas nepotism is deliberate efforts by an official by utilizing his position and position to benefit the position, rank and career of himself, family, or close friends in ways that are unfair or unlawful. Nepotism comes from the word nepos which literally means grandson. This term is closer to the term "family system", spoil system, corruption of position, and so on. Nepotism is done at in the process of selecting or appointing people in certain positions who sometimes do not go through rational ways and open selection processes but only depend on their likes or dislikes, or the closeness of friendship and kinship relations (Dwiyanto, et.al, 2006: 100- 101).

In reality, the application of the phenomenon of $\mathrm{KKN}$ is considered or carried out by anyone categorized as a problem of KKN. The problem is that there is no clarity about what is meant by KKN with operational definitions and detailed criteria so that the implementation of provisions regarding $\mathrm{KKN}$ is sometimes not the same between one person and another. The emergence of various definitions related to corruption shows that corruption as a social, economic and political phenomenon in practice can take various patterns of behavior and forms. Corruption can be carried out by the lowest administrative apparatus to officials, and corruption also involves the amount of money, and involves in the number of people. Categorization may be needed because it can be used as a guide to understanding patterns of corruption, and the ways or modus operandi. According to Syaed Hussein Alatas in Dwiyanta, et. Al (2006: 102), shows seven categories of corruption, namely corruption (transactive corruption), extortive corruption, investive corruption, kinship corruption or nepotism (nepotistic corruption). ), defect corruption (defensive corruption), autogenic corruption (autogenic corruption), and support corruption (supportive corruption). Furthermore, in Dwiyanto, et. Al. (2006: 102), transactive corruption is caused by a mutual agreement between the giver and the recipient for mutual benefit and both parties actively seek these benefits. Transactive corruption usually involves government officials with businesses or community leaders and certain government officials. Extortion is corruption where the giver is forced to give a bribe to prevent losses that are threatening him, his interests, or something of value to him. Defensive corruption refers to the behavior of victims of corruption with extortion, so corruption is carried out in order to defend themselves. Including as a practice of defensive corruption is a person who interrupts, because if they do not do so the business will be hampered or stopped. Some authors consider that actions like this do not include corruption because someone's position here is as a victim of corruption itself. But if corruption is returned to its original meaning as "dishonesty" or "decay", defensive corruption still has a negative effect because of the element of 
allowing crime. Furthermore in Dwiyanto, et.al (2006: 102-103), what is meant by inventive corruption is the provision of goods or services without obtaining certain benefits, in addition to profits that are still in wishful thinking or that are expected to be obtained in the future. Nepotism or kinship corruption, as explained, is the illegal appointment of relatives or close friends to occupy positions in the government. Rewards that are contrary to the norms and regulations may be in the form of money, special facilities, power, etc. Ontogenic corruption is a form of corruption that does not involve other people and the perpetrators are only one person. A DPR member who supports the enactment of a law regardless of its consequences while reaping financial benefits from his knowledge of the law can be categorized as an autogenic corruption actor. The last category is corruption of support, namely corruption committed to protect or strengthen existing and future corruption. The method used in support corruption may be very cunning. For example, people who pay vandals to expel honest voters at the polls, allow the riots to occur, hinder honest officials from occupying certain strategic positions, and so on.

The phenomenon of KKN, if it has been infected in the government bureaucracy, then the form of abuse of authority and corruption transactions can vary, such as tribute, commissions, bribes, parcels or parcels to become a powerful tool for entrepreneurs or the public who have affairs with officials government. Misappropriation in government does not only involve service to citizens but also involves assessing appointments in certain positions. Misappropriation in service, we may have often heard with a mode to help ease service arrangements, so that people must add extra costs as a form of incentives given to organizers because they have been given convenience in the service process. Deviations in one's judgment to occupy a position also often occur, this is a lot of cases of regents and or heads of service dealing with the KPK because of buying and selling positions. Likewise in serving superiors both structurally and functionally, for example, the BPK will evaluate and clarify regional financial budgets, so regional officials will usually try to provide excessive services or services in accordance with the pleasure of future BPK officials, with the aim of checking and / or budget clarification is not too critical and if there are findings, opportunities are given to make improvements.

The impact that can be caused from corruption can endanger and hinder the realization of good governance practices, and can damage the morale of the nation and the joints of life of a nation. From the above thought, a concept was created that corruption of public bureaucracy influences the quality of public service delivery. For this reason, the following hypothesis is constructed by the relationship between variables, namely:

$H O=$ There is an influence between corruption of the public ureaucracy towards the quality of public service delivery,

$H a=$ There is no influence between corruption of public bureaucracy towards the quality of public service delivery.

While the orientation and direction of research can be described in the diagram as follows:

Picture. 1

Corruption of Public Bureaucracy, its relation to the Quality of Public Services

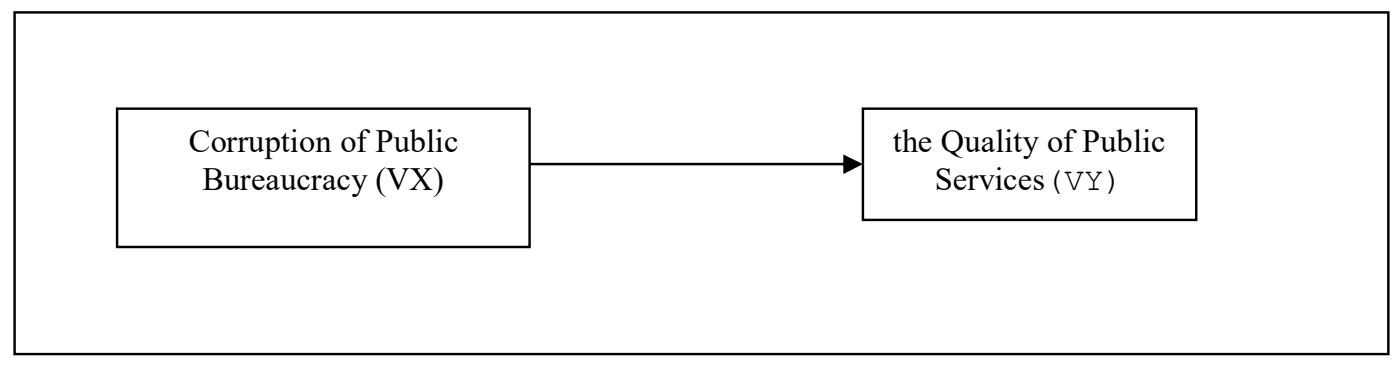

\section{RESEARCH METHODS.}

This study uses a quantitative approach to determine respondents' assessment of the factors of public bureaucratic corruption, and the quality of public service delivery. Data was collected through distributing questionnaires to 120 respondents who were randomly selected in 6 kelurahan, Ponorogo Regency. Each village was assigned 20 respondents by random sampling, which consisted of: 8 employees, and 12 community service users. Respondents' assessment was measured using a Likert scale with gradations from very positive to very negative, in the form of words such as: a) Strongly agreed with a score of 5, b) agreed with a score of 4, c) 
Hesitated with a score of 3, d) No agree with the score 2, and e) Strongly disagree with the score 1 . While the method of data analysis uses a regression analysis model with processing through SPSS.

\section{RESULTS AND DISCUSSION.}

\section{Test Correlation.}

To test the hypothesis is tested correlation between Corruption of Public Bureaucracy variable (VX) as independent variable to the Quality of Public Services (VY) as dependent variable. The result of correlation test as the table below.

Table. 1

Correlation Test Results between the variables of Corruption of Public Bureaucracy and the Quality of Public Services

\section{Correlations}

\begin{tabular}{|c|c|c|c|}
\hline & & $\begin{array}{c}\text { Corruption of } \\
\text { Public Bureaucracy }\end{array}$ & $\begin{array}{c}\text { The Quality of Public } \\
\text { Services }\end{array}$ \\
\hline $\begin{array}{l}\text { Corruption of Public } \\
\text { Bureaucracy }\end{array}$ & $\begin{array}{l}\text { Pearson Correlation } \\
\text { Sig. (2-tailed) } \\
\mathrm{N}\end{array}$ & $\begin{array}{r}1 \\
150\end{array}$ & $\begin{array}{r}.806^{* *} \\
.000 \\
150\end{array}$ \\
\hline $\begin{array}{l}\text { The Quality of Public } \\
\text { Services }\end{array}$ & $\begin{array}{l}\text { Pearson Correlation } \\
\text { Sig. (2-tailed) } \\
\text { N }\end{array}$ & $\begin{array}{r}.806^{* *} \\
.000 \\
150\end{array}$ & $\begin{array}{r}1 \\
150\end{array}$ \\
\hline
\end{tabular}

**. Correlation is significant at the 0.01 level (2-tailed).

From the table above, the value of the correlation between the variables of corruption of public bureaucracy with the variable quality of public service is equal to 0.806 with a value of pvalue $=0,000$. When compared with the value of $\alpha=0.05$, it is known that $p$ value $=(0,000)<\alpha(0.05)$. Thus, the Ha hypothesis is accepted, namely there is a correlation between the corruption of public bureaucracy and the quality of public services.

\section{Regression Test}

The result of regression calculation between Corruption of Public Bureaucracy variable to the Quality of Public Services, can be seen table below.

Table. 2

Regression Test Results between the variables of Corruption of Public Bureaucracy and the Quality of Public Services

\section{Coefficients $^{\mathbf{a}}$}

\begin{tabular}{|c|c|c|c|c|c|c|}
\hline \multirow{2}{*}{\multicolumn{2}{|c|}{ Model }} & \multicolumn{2}{|c|}{ Unstandardized Coefficients } & \multirow{2}{*}{$\begin{array}{c}\text { Standardized } \\
\text { Coefficients }\end{array}$} & \multirow[b]{2}{*}{$\mathrm{t}$} & \multirow[b]{2}{*}{ Sig. } \\
\hline & & $\mathrm{B}$ & Std. Error & & & \\
\hline 1 & (Constant) & 14.415 & 2.400 & & 6.007 & .000 \\
\hline & $\begin{array}{l}\text { Corruption of Public } \\
\text { Bureaucracy }\end{array}$ & .674 & .041 & .806 & 16.563 & .000 \\
\hline
\end{tabular}

a. Dependent Variable: Corruption of Public Bureaucracy

From the regression equation $(\mathrm{Y}=\mathrm{a}+\mathrm{bX})$, it can be identified: (1) Constant value 14.415; indicates that public bureaucratic corruption will be constant if the variable quality of public services is zero (none), assuming other factors remain or do not change in value. (2) Variables of public bureaucratic corruption worth 0.674 (positive) indicate the influence of public bureaucratic corruption on the quality of public services. If corruption of the public bureaucracy increases by 1 unit, the quality of public services also decreases by 0.674 . Thus the corruption of public bureaucracy has a positive effect on the quality of public services. 
Determination Test.

The coefficient of determination (R2) is used to measure how far the model's ability to explain variations in the dependent variable (Ghozali, 2006). The test results of the coefficient of determination are:

Table. 3

Determination Regression Test Results between the variables of Corruption of Public Bureaucracy and the Quality of Public Services

\begin{tabular}{|l|r|r|r|r|}
\hline Model & R & R Square & $\begin{array}{c}\text { Adjusted R } \\
\text { Square }\end{array}$ & $\begin{array}{c}\text { Std. Error of the } \\
\text { Estimate }\end{array}$ \\
\hline 1 & $.806^{\mathrm{a}}$ & .650 & .647 & 4.726 \\
\hline
\end{tabular}

The amount of Multiple Coefficient of Determination (R Square) is 0.650 or $65.0 \%$ which means that the quality of public services can be explained by the variables of public bureaucratic corruption, while the remaining $35.0 \%$ is explained by other variables not explained in this study. The quality of public services is very dependent on bureaucratic behavior in addressing the bureaucratic vision as a public servant. In reality there is still a lot of bureaucratic behavior that shows itself as an official or ruler who can determine the speed or failure of public services, this attitude of bureaucratic officials is the beginning of the emergence of corrupt practices in public services. Society is considered as an object that is obliged to provide services to bureaucratic officials if they want convenience in public services. Besides that, the behavior of bureaucratic corruption can also be explained because of leadership factors because leaders are role models for their employees. For this reason, a strong commitment from the leadership is needed to eliminate bribery in the environment of public service delivery.

\section{CONCLUSION.}

The practice of bribery as a form of corruption, and has become a tradition that developed in the bureaucratic environment is no exception at the level of village government. The practice of bribery in public services was assessed as a thank you to the community for the ease in managing services provided by bureaucratic officials. As a result, the bureaucratic apparatus became accustomed to the service culture that hoped for the provision of money from the community. Bribery practices in public services will hamper community activities in various fields of life, therefore as a recommendation it can be stated: to make changes to the bureaucratic apparatus through structured guidance by returning to their functions as public servants, who prioritize the interests of the community.

\section{CONFLICT OF INTEREST}

There is no conflict of interest.

\section{ACKNOWLEDGMENTS}

This article is sponsored by the Kemenristik-Dikti Indonesian Research Grants Program.

\section{REFERENCES}

Alamsyah, D, 2011, Manajemen Pelayanan Kesehatan. Yogyakarta: Penerbit Nuha Medika.

Dwiyanto, Agus, dkk. 2002, Reformasi Birokrasi Publik, Yogyakarta : Gajah Mada University Press.

Dwiyanto, et.al, 2006, Mewujudkan Good Governance Melalui Pelayanan Publik. Yogyakarta: Gajah Mada University Press.

Effendi, Onong Uchjana, 1977, Human Relation dan Public Relation Dalam Management, Bandung, Penerbit Alumni.

Ghozali, Imam, 2006, Aplikasi Analisis Multivariate Dengan Program SPSS, Badan Penerbit Universitas Diponegoro, Semarang.

Pasolong, Harbani. 2007. Teori Administrasi Publik. Bandung: Penerbit ALFABETA.

Rahmat Subagio, 2012, Analisis Penerapan Reformasi Birokrasi Pada Kantor Pelayanan Utama Bea dan Cukai Tanjung Priok, Tesis, Fakultas Ilmu Sosial Dan Ilmu Politik, Program Studi Administrasi Negara Dan Kebijakan Publik Jakarta_lib.ui.ac.id/file?file... Tesis\%20Rahmat\%20Subagio\%20090665558...diakses Tanggal $1 \overline{10 \text { April } 2019 .}$ 
Rasyid, Ryaas, 1998. Makna Pemerintahan: Tinjauan Dari Segi Etika dan. Kepemimpinan, Jakarta: Yarif Watampone. 